\title{
Developments and emerging trends in PD-L1 research in gastrointestinal cancers (2000-2018): a bibliometric perspective
}

\section{Guangyi Jiang}

Zhejiang University School of Medicine Sir Run Run Shaw Hospital

\section{Xinjie Zhang}

Zhejiang University School of Medicine Sir Run Run Shaw Hospital

Hui Liu

Zhejiang University School of Medicine Sir Run Run Shaw Hospital

Xingyu Lv

Zhejiang University School of Medicine Sir Run Run Shaw Hospital

\section{Fangqiang Wei}

Zhejiang Provincial People's Hospital

\section{Tunan Yu}

Zhejiang University School of Medicine Sir Run Run Shaw Hospital

\section{Xiujun Cai ( $\nabla$ srrsh_cxj@zju.edu.cn )}

Zhejiang University School of Medicine Sir Run Run Shaw Hospital https://orcid.org/0000-0002-64570577

\section{Research article}

Keywords: PD-L1, gastrointestinal cancer, immune checkpoint inhibitor, CiteSpace, bibliometric method

Posted Date: December 12th, 2019

DOI: https://doi.org/10.21203/rs.2.18561/v1

License: (c) (1) This work is licensed under a Creative Commons Attribution 4.0 International License. Read Full License 


\section{Abstract}

Background: The programmed death-ligand 1 (PD-L1) pathway inhibits T-cell receptor-mediated production of IL-2 and T-cell proliferation and plays an important role in the immunosuppression of various types of cancers. An increasing number of studies have focused on the potential utilization of anti-PD-L1 therapy in gastrointestinal cancers. In this study, we aimed to analyze developments and emerging trends in studies of PD-L1 in gastrointestinal cancers from a bibliometric perspective.

Methods: Manuscripts were retrieved from th Web of Science Core Collection (WOSCC) Database. CiteSpace, a bibliometric software, was used to identify landmark studies, key concepts, and various subtopics in this research area.

Results: A total of 1325 manuscripts examining PD-L1 in gastrointestinal cancers were included. Manuscripts published in 2017 and 2018 accounted for almost half of the publications $(44.2 \%$, $586 / 1325)$. Combined with 31,960 references, the manuscripts on this topic constituted a complex cocitation network, and landmark papers were identified by indexes including citation in the network, betweenness centrality, and burstiness . Key concepts such as "Regulatory T cell," "TIL," and "Her2" were identified in the co-citation network for author keywords. Furthermore, several subtopics were identified during the process of "clustering" in colorectal, gastroesophageal, and hepatopancreatobiliary cancers, such as "predictive biomarkers", "advanced cancers", and "clinical efficacy".

Conclusions: Research on PD-L1 i n gastrointestinal cancers is a rapidly progressing area. More scientific findings are expected in the near future. Analysis and summarization from a bibliometric perspective not onlyidentify landmark manuscripts and hot-spot concepts but also indicate possible directions for future studies.

\section{Background}

Immunotherapy plays an important role in clinical cancer therapy, and many checkpoints have been discovered for tumor suppression. Immune checkpoint therapy, mainly anti-programmed death-1 (PD-1) and PD ligand 1 (PD-L1) therapy, can enhance antitumor immune responses by blocking the inhibitory signals of the immune system. PD-L1, also known as CD274, was first discovered by Dong et al [1] in 1999 as an immune regulatory molecule called B7-H1. Later, B7-H1 was renamed PD-L1 because it was identified as the ligand of PD-1. Moreover, blockade of B7-H1 reduced the growth of tumors in the presence of immune cells. Importantly, Dong et al [2] published a landmark paper reporting that tumors with PD-L1 expression had increased T-cell apoptosis. Engagement of PD-L1 with its receptor PD-1, which is expressed on T cells, inhibits T-cell receptor (TCR)-mediated activation of IL-2 production and T-cell proliferation. The interaction between PD-L1 and PD-1 also contributes to ligand-induced TCR downmodulation during antigen presentation to naive T cells [3]. This significant finding promoted PD-L1 as a potential target in cancer immunotherapy. Currently, several PD-L1 antagonists (avelumab, 
durvalumab, and atezolizumab) are approved by the US Food and Drug Administration for various indications, especially in treating non-small cell lung cancer (NSCLC) and melanoma [4-7].

Several high-quality clinical studies have examined antagonists of PD-1 in various gastrointestinal cancers. El-Khoueiry et al [8] reported that nivolumab had a manageable profile and durable objective responses in advanced hepatocellular carcinoma. Shitara et al [9] assessed combination pembrolizumab and paclitaxel to treat gastric or gastroesophageal junction cancer. Although no significant improvement of overall survival was observed for this new strategy, pembrolizumab had a better safety profile than paclitaxel. The favorable results of PD-1 blockade suggested the possibility and potential clinical utilization of blockading PD-L1 in gastrointestinal malignancies. Through February 1, 2019, a total of 22, $23,21,15$, and 10 clinical trials had been registered for anti-PD-L1 therapies in esophageal, gastric, colorectal, pancreatic, and hepatocellular carcinoma, respectively [10].

Several reviews have already been published on the frontier PD-L1 research in clinical applications. However, analysis with a bibliometric method, which relies on an artificial intelligence-based algorithm to landmark manuscripts, hotspots, and emerging trends in a research area, has not been done. In this study, we used CiteSpace [11], a bibliometric software, to summarize current research about PD-L1 in gastrointestinal cancers and explore possible directions for future studies.

\section{Results}

\section{Basic characteristics of manuscripts}

A total of 1325 manuscripts in the area of PD-L1 in gastrointestinal cancers were retrieved. Among these manuscripts, there were 899 original articles (67.8\%), 232 reviews (17.5\%), 156 meeting abstracts $(11.8 \%), 25$ editorial materials $(1.9 \%), 14$ proceeding papers $(1.1 \%)$, and 12 other documents $(0.9 \%)$. One thousand three hundred thirteen manuscripts $(99.1 \%)$ were written in English. Based on the calculator in WOS, each manuscript was cited 30.72 times. PD-L1 was also searched in different types of gastrointestinal cancers. The number of publications in gastric, esophageal, colon, pancreatic, hepatocellular, biliary, appendiceal, and small intestinal cancers were $345,109,560,252,278,15,0$, and 0 , respectively.

Institutions in 54 countries and areas participated in publication of these manuscripts. The United States (489), China (377), and Japan (172) published most of the manuscripts. The top 5 institutions publishing manuscripts were Harvard University (55), the University of Texas system (51), the VA Boston Healthcare System (50), Johns Hopkins University (42), and the Institut National de la Santé et de la Recherche Médicale (40).

Before 2010, only a few studies were published each year. In 2010, only 12 manuscripts were published. However, since 2011, the annual number of publications sharply increased (Figure 1). In 2018, 458 manuscripts were published. Additionally, manuscripts published in 2017 and 2018 accounted for almost half of the retrieved publications $(44.2 \%, 586 / 1325)$. Moreover, the percentage of publications on PD-L1 
focusing on gastrointestinal cancers increased over time. In 2010, gastrointestinal cancers accounted for only $5.8 \%(12 / 27)$ of all studies on PD-L1. However, in 2018, they accounted for $14.9 \%$ (458/3081) (Figure 2).

\section{Overview of landmark manuscripts}

The 1325 manuscripts about PD-L1 in gastrointestinal cancers also cited each other or some other literature in their references. Combined with their 31,960 references, a simplified co-citation network (Figure 3) of the manuscripts was constructed on the condition of the g-index as 5 . In Figure 3 , the 5 manuscripts according to the value of total citations were marked. They were summarized in Table 1 with the top 5 manuscripts according to the value of betweenness centrality and burstness.

Furthermore, since almost half (44.2\%) of the manuscripts were published in 2017 and 2018, a co-citation network of all literatures during these 2 years was created. The top 5 manuscripts with the highest citation amount in the co-citation network are summarized in Table 2.

\section{Key concepts in the research area}

To identify key concepts about PD-L1 in gastrointestinal malignancies, a foam tree was constructed using the Carrot2 analytic software. The top 5 keywords with the highest frequency were circled with red line, as "gastric cancer," "therapies for the treatment," "colorectal cancer," "PD-1 for the treatment," and "CD8 T cells and tumor" (Figure 4).

Further, to detect novel concepts since 2014 (recent five years), a simplified co-citation network of author keywords (restricted with the condition of the top 50 phrases per year) was created (Figure5). In this map, three words with highest citation were "colorectal cancer", "immunotherapy" and "pd-11".. Several such phrases with greater scientific importance are illustrated in Table 3, including three emerging between 2014 and 2015 ("Immunosuppression," "IFN-gamma," and "Regulatory t cell"), two emerging between 2015 and 2016 ("Ipilimumab" and "Mdsc"), one emerging between 2015 and 2018 ("Solid tumor"), and four emerging between 2016 and 2018 (“TIL," “Her2," “Radiation," and "Atezolizumab").

\section{Topics in various gastrointestinal cancer types}

To understand different subtopics in various gastrointestinal cancer types, a unique process termed "clustering" was utilized. Simplified co-citation networks (restriction on the condition of the g-index as 5) were constructed for colorectal, gastroesophageal, and hepatopancreatobiliary cancers, and studies in these three cancers were divided into 32, 23, and 25 clusters, respectively (Figure 6). The three largest clusters in each disease were summarized from the titles of manuscripts in the cluster (Table 4), which reflected the contents of each cluster. For example, in colorectal cancers, the terms summarizing the largest three clusters were "predictive biomarkers," "advanced cancer," and "prognostic significance."

\section{Discussion}


The clinical utilization of PD-L1 antagonists initially focused on NSCLC and melanoma. Herbst et al [49] performed a randomized controlled trial comparing pembrolizumab and docetaxel for treating NSCLC, which suggested that pembrolizumab prolongs overall survival in patients with previously treated PD-L1positive NSCLC. Buchbinder et al [50] found that a high dose of IL-2 enhanced the effect of PD-L1 inhibitor in melanoma patients. From 2000 to 2018, an increasing number of studies were conducted to explore the mechanism and clinical utilization of PD-L1 antagonists in gastrointestinal cancers, which possibly provided new strategies for immunotherapy in the future.

Although several reviews have already discussed the current state of PD-L1 in gastrointestinal cancers, a systemic analysis of all literatures and correlated manuscripts in this area was lacking [51,52]. According to our results, over 1300 manuscripts have been published on this topic, with over 30,000 combined references. The citations between these papers constitute an extremely complex co-citation network. Therefore, traditional reviews, which are mainly based on expert opinions, are limited in their ability to summarize such difficult correlations. Here, we used the bibliometric software CiteSpace, which is userfriendly and easily mastered by researchers without a scientometric background, to summarize the current state of this field. In this study, combined with data analyses from the WOSCC Database, several important findings were made.

First, the topic of PD-L1 in gastrointestinal cancers was attracting increasing attention from researchers during these years. Publications in 2017 and 2018 accounted for almost half (44.2\%) of the total publications between 2000 and 2018. Comparatively, before 2010, the total number of publications was only 51. Furthermore, in the whole domain of PD-L1, the percentage of publications on gastrointestinal cancers increased over time. In 2010, the percentage of PD-L1 studies in gastrointestinal cancers was only $5.8 \%(12 / 27)$, but it had more than doubled by $2018(14.9 \%, 458 / 3081)$.

Second, by analyzing the co-citation network for papers, several landmark manuscripts were identified (Tables 1 and 2); some directly investigated PD-L1 in gastrointestinal cancers. For example, in the clinical study by Brahmer et al [13] administering anti-PD-L1 antibody, 8 patients with colorectal cancer, 14 with pancreatic cancer, and 7 with gastric cancer were recruited. However, no objective responses in patients with colorectal or pancreatic cancer were observed. In the study by Thompson et al [24], gastric or gastroesophageal junction cancer patients who had higher PD-L1 expression had higher CD8 + T-cell densities. These expressions were correlated with prognosis.

Furthermore, the analysis of the literature co-citation network also suggested some important studies that were not directly related to PD-L1 or gastrointestinal cancers but indicated directions for future studies. The studies by El-Khoueiry et al [8] and Kang et al [25] established the role of nivolumab, a PD-1 inhibitor, in treating hepatocellular carcinoma and gastric or gastroesophageal junction cancer. Therefore, whether PD-L1 blockade could also be beneficial in similar clinical conditions is worth studying. Gopalakrishnan et al [27] reported that the gut microbiome modulates response to anti-PD-1 immunotherapy in melanoma patients, and Routy B et al [28] found that the gut microbiome can also affect the efficacy of PD-1 antagonists in epithelial tumors. It is well-known that the gut microbiome plays an important role in the 
development of gastrointestinal cancers [53,54]. Hence, whether the gut microbiome participates in the oncogenesis and metastasis of gastrointestinal tumors through the PD1/PD-L1 pathway is worth studying. Additionally, the studies of Hellmann et al [30] and Mariathasan et al [31] indicate the possibility of combining a PD-L1 antagonist with another agent (TGF-b blocking) in melanoma and urothelial cancer; whether this therapeutic strategy could work in gastrointestinal cancers needs validation.

Third, by analyzing author keywords and "clustering," some important phrases were identified. In the cocitation network of author keywords, "TIL," "Her2," and "Radiation" were identified to have high burstiness. TILs, or tumor infiltrating lymphocytes, are considered predictive markers when combined with PD-L1 expression. In the study by Cariani et al [55], PD-L1 combined with TILs could better predict the prognosis of hepatocellular carcinoma. Her2 is a frequently measured molecular marker in various types of cancers. In the study by Li et al [39] on gastric cancer, the expressions of Her2 and PD-L1 were correlated, indicating the possibility of a combined therapeutic strategy. Radiation together with chemotherapy was of clinical efficacy in rectal cancer. In Hecht's study [40] on rectal cancer, PD-L1 was upregulated by chemoradiotherapy, suggesting the possibility of using a PD-L1 antagonist with traditional radiation or chemotherapy. During the process of clustering, some phrases were also identified. For instance, the terms "advanced cancer", "metastatic gastric cancer" were identified. Currently, most of clinical studies focusing on immune checkpoints were done in patients with advanced cancers $[8,9,49]$. Whether these medications would be useful for patients at eariler stage or after curative resection need to be validated in future. There were mainly two limitations of this study. One was that the co-citation analyses were only done in papers derived from the WOSCC. Results from other databases such as PubMed, Scopus were not seperately analyzed. The other was that among all the bibilometric softwares, mainly CiteSpace was utilized. The software of VOSviewer, CitNetExplorer and HistCite could provide similar partial function of CiteSpace. However, the visuliaztion of science map based on CiteSpace was easiler to be understood by researcher without background of scientometrics.

\section{Conclusion}

In conclusion, research about PD-L1 in gastrointestinal cancers is a rapidly progressing area. More scientific findings are expected in the near future. Analysis and summarization from a bibliometric perspective not only identify landmark manuscripts and hot-spot concepts, but also indicate possible directions for future studies.

\section{Methods}

A query of the literature about PD-L1 in gastrointestinal cancers was conducted on the Web of Science Core Citation (WOSCC) Database. The search was conducted for studies published from January 1, 2000, since the first study on PD-L1 was published in December 1999, to December 31, 2018 [1]. To find manuscripts focusing on PD-L1, several synonyms, including "pdl1," "pd-11," "programmed cell death 1 ligand 1 protein," "B7-H1," "B7H1," “CD274," "cluster of differentiation 274," and "CD 274" (search result $\left.D_{A}\right)$, were utilized. Several types of gastrointestinal cancers were also searched, including "gastric cancer," 
"esophageal cancer," "colon cancer" ("colorectal cancer"), "pancreatic cancer," "hepatocellular carcinoma," "biliary cancer," "appendiceal cancer," and "small intestinal cancer" (search result $D_{B}$ ). Then, $D_{A}$ was searched with $D_{B}$ using the Boolean symbol "AND".

The CiteSpace V 5.3.R4 (64 bits), a bibliometric application invented by Professor Chaomei Chen [11], was utilized for most of the intellectual analyses in this study. Several functions were utilized. First, to identify landmark papers, a co-citation network was constructed, in which each node represents a manuscript (including the reference paper) and each link represents the relation of citing. The network could be constructed in a completed manner to include all the manuscripts and references, or in a simplified manner that neglects studies with a minimum chance of citations (restriction with g-index [56]; the scale factor $k$ was set as 5). In co-citation networks, the importance of each node could be measured by its total citation amount in the network or the value of betweenness centrality [57] and burstiness [58]. In this study, a landmark manuscript was defined as a paper ranked top 5 according to these three indexes.

Second, to identify key concepts evolving through time, author keywords in all manuscripts were utilized to construct a co-citation network and simplified by the condition that only phrases with a top 50 citation amount were used per year. Then, the burstiness of each keyword was measured. High burstiness indicated that the citation counts sharply increased over time. The keywords with high burstiness and scientific significance were analyzed. Additionally, we used the software Carrot2 [59] to identify important keywords directly from the title of each manuscript. The results of the Carrot2 analysis were visualized as a "foam tree."

Third to understand different topics in various gastrointestinal cancers, a unique process called "clustering" was performed in the simplified co-citation networks (restriction of g-index of 5) of colorectal, gastroesophageal, and hepatopancreatobiliary cancers. The quality of clustering was measured by two indexes, modularity and silhouette score [60]. Finally, the label of each cluster was summarized with the method of log-likelihood, which represents the subtopics of each disease.

\section{Abbreviations}

PD-L1: programmed death-ligand 1; PD-1: programmed cell death protein 1; TCR: T-cell receptor; WOSCC: Web of Science Core Collection; NSCLC: non-small cell lung cancer; TIL: tumor infiltrating lymphocytes

\section{Declarations}

\section{Ethics approval and consent to participate}

Not applicable.

\section{Consent for publication}


Not applicable

\section{Competing interests}

The authors declare that they have no competing interests.

\section{Funding}

This research was supported by Zhejiang Provincial Natural Science Foundation of China under Grant Nos. LQ17H030003 (Tunan Yu) and LQ17H260001 (Hui Liu).

\section{Authors' contributions}

TNY and XJC conceived the study and performed critical revision of manuscript. TNY, GYJ, XYL, HL and QZ designed the study, performed statistical analyses and drafted the manuscript. GYJ and TNY wrote the manuscript. TNY and XJC performed the article retrieval, data interpretation and provided supervision. All authors read and approved the final manuscript

\section{Availability of data and materials}

The datasets during and/or analyzed during the current study are available

from the corresponding author on reasonable request.

\section{Acknowledgment}

Not applicable

\section{Reference}

1. Dong H, Zhu G, Tamada K, Chen L. B7-H1, a third member of the B7 family, co-stimulates T-cell proliferation and interleukin-10 secretion. Nat Med. 1999 Dec;5(12):1365-9.

2. Dong H, Strome SE, Salomao DR, Tamura H, Hirano F, Flies DB, et al. Tumor-associated B7-H1 promotes T-cell apoptosis: a potential mechanism of immune evasion. Nat Med. 2002 Aug;8(8):793800.

3. Karwacz K, Bricogne C, MacDonald D, Arce F, Bennett CL, Collins M, et al. PD-L1 co-stimulation contributes to ligand-induced $\mathrm{T}$ cell receptor down-modulation on CD8+ T cells. EMBO Mol Med. 2011 Oct;3(10):581-92.

4. Sui H, Ma N, Wang Y, Li H, Liu X, Su Y, et al. Anti-PD-1/PD-L1 Therapy for Non-Small-Cell Lung Cancer: Toward Personalized Medicine and Combination Strategies. J Immunol Res. 2018;2018:6984948.

5. Bylicki O, Paleiron N, Rousseau-Bussac G, Chouaid C. New PDL1 inhibitors for non-small cell lung cancer: focus on pembrolizumab. Onco Targets Ther. 2018;11:4051-64. 
6. Wolchok JD, Chiarion-Sileni V, Gonzalez R, Rutkowski P, Grob J-J, Cowey CL, et al. Overall Survival with Combined Nivolumab and Ipilimumab in Advanced Melanoma. N Engl J Med. 2017 Oct;377(14):1345-56.

7. Scott LJ. Nivolumab: A Review in Advanced Melanoma. Drugs. 2015 Aug;75(12):1413-24.

8. El-Khoueiry AB, Sangro B, Yau T, Crocenzi TS, Kudo M, Hsu C, et al. Nivolumab in patients with advanced hepatocellular carcinoma (CheckMate 040): an open-label, non-comparative, phase 1/2 dose escalation and expansion trial. Lancet (London, England). 2017 Jun;389(10088):2492-502.

9. Shitara K, Ozguroglu M, Bang Y-J, Di Bartolomeo M, Mandala M, Ryu M-H, et al. Pembrolizumab versus paclitaxel for previously treated, advanced gastric or gastro-oesophageal junction cancer (KEYNOTE-061): a randomised, open-label, controlled, phase 3 trial. Lancet (London, England). 2018 Jul;392(10142):123-33.

10. https://www.clinicaltrials.gov/.

11. Synnestvedt MB, Chen C, Holmes JH. CiteSpace II: visualization and knowledge discovery in bibliographic databases. AMIA . Annu Symp proceedings AMIA Symp. 2005;724-8.

12. Topalian SL, Hodi FS, Brahmer JR, Gettinger SN, Smith DC, McDermott DF, et al. Safety, activity, and immune correlates of anti-PD-1 antibody in cancer. N Engl J Med. 2012 Jun;366(26):2443-54.

13. Brahmer JR, Tykodi SS, Chow LQM, Hwu W-J, Topalian SL, Hwu P, et al. Safety and activity of antiPD-L1 antibody in patients with advanced cancer. N Engl J Med. 2012 Jun;366(26):2455-65.

14. Herbst RS, Soria J-C, Kowanetz M, Fine GD, Hamid O, Gordon MS, et al. Predictive correlates of response to the anti-PD-L1 antibody MPDL3280A in cancer patients. Nature. 2014 Nov;515(7528):563-7.

15. Pardoll DM. The blockade of immune checkpoints in cancer immunotherapy. 2012;12(April). Available from: http://dx.doi.org/10.1038/nrc3239

16. Skora AD, Luber BS, Azad NS, Laheru D, Biedrzycki B, Donehower RC, et al. PD-1 Blockade in Tumors with Mismatch-Repair Deficiency. 2015;1-12.

17. Keir ME, Butte MJ, Freeman GJ, Sharpe AH. PD-1 and its ligands in tolerance and immunity. Annu Rev Immunol. 2008;26:677-704.

18. Droeser RA, Hirt C, Viehl CT, Frey DM, Nebiker C, Huber X, et al. Clinical impact of programmed cell death ligand 1 expression in colorectal cancer. Eur J Cancer. 2013 Jun;49(9):2233-42.

19. Berger R, Rotem-Yehudar R, Slama G, Landes S, Kneller A, Leiba M, et al. Phase I safety and pharmacokinetic study of CT-011, a humanized antibody interacting with PD-1, in patients with advanced hematologic malignancies. Clin Cancer Res. 2008 May;14(10):3044-51.

20. Topalian SL, Drake CG, Pardoll DM. Targeting the PD-1/B7-H1(PD-L1) pathway to activate anti-tumor immunity. Curr Opin Immunol. 2012 Apr;24(2):207-12.

21. Blank C, Brown I, Peterson AC, Spiotto M, Iwai Y, Honjo T, et al. PD-L1/B7H-1 inhibits the effector phase of tumor rejection by T cell receptor (TCR) transgenic CD8+ T cells. Cancer Res. 2004 Feb;64(3):1140-5. 
22. Konishi J, Yamazaki K, Azuma M, Kinoshita I, Dosaka-Akita H, Nishimura M. B7-H1 expression on non-small cell lung cancer cells and its relationship with tumor-infiltrating lymphocytes and their PD1 expression. Clin Cancer Res. 2004 Aug;10(15):5094-100.

23. Le DT, Durham JN, Smith KN, Wang H, Bartlett BR, Aulakh LK, et al. Mismatch repair deficiency predicts response of solid tumors to PD-1 blockade. Science. 2017 Jul;357(6349):409-13.

24. Thompson ED, Zahurak M, Murphy A, Cornish T, Cuka N, Abdelfatah E, et al. Patterns of PD-L1 expression and CD8 T cell infiltration in gastric adenocarcinomas and associated immune stroma. Gut. 2017 May;66(5):794-801.

25. Kang Y-K, Boku N, Satoh T, Ryu M-H, Chao Y, Kato K, et al. Nivolumab in patients with advanced gastric or gastro-oesophageal junction cancer refractory to, or intolerant of, at least two previous chemotherapy regimens (ONO-4538-12, ATTRACTION-2): a randomised, double-blind, placebocontrolled, phase 3 trial. Lancet (London, England). 2017 Dec;390(10111):2461-71.

26. Chen DS, Mellman I. Elements of cancer immunity and the cancer-immune set point. Nature. 2017 Jan;541(7637):321-30.

27. Gopalakrishnan V, Spencer CN, Nezi L, Reuben A, Andrews MC, Karpinets T V, et al. Gut microbiome modulates response to anti-PD-1 immunotherapy in melanoma patients. Science. 2018 Jan;359(6371):97-103.

28. Routy B, Le Chatelier E, Derosa L, Duong CPM, Alou MT, Daillere R, et al. Gut microbiome influences efficacy of PD-1-based immunotherapy against epithelial tumors. Science. 2018 Jan;359(6371):917.

29. Matson V, Fessler J, Bao R, Chongsuwat T, Zha Y, Alegre M-L, et al. The commensal microbiome is associated with anti-PD-1 efficacy in metastatic melanoma patients. Science. 2018 Jan;359(6371):104-8.

30. Hellmann MD, Ciuleanu T-E, Pluzanski A, Lee JS, Otterson GA, Audigier-Valette C, et al. Nivolumab plus Ipilimumab in Lung Cancer with a High Tumor Mutational Burden. N Engl J Med. 2018 May;378(22):2093-104.

31. Mariathasan S, Turley SJ, Nickles D, Castiglioni A, Yuen K, Wang Y, et al. TGFbeta attenuates tumour response to PD-L1 blockade by contributing to exclusion of T cells. Nature. 2018 Feb;554(7693):544-8.

32. Burga RA, Thorn M, Point GR, Guha P, Nguyen CT, Licata LA, et al. Liver myeloid-derived suppressor cells expand in response to liver metastases in mice and inhibit the anti-tumor efficacy of anti-CEA CAR-T. Cancer Immunol Immunother. 2015 Jul;64(7):817-29.

33. Tseng H-C, Bui V, Man Y-G, Cacalano N, Jewett A. Induction of Split Anergy Conditions Natural Killer Cells to Promote Differentiation of Stem Cells through Cell-Cell Contact and Secreted Factors. Front Immunol. 2014;5:269.

34. Sun S, Fei X, Mao Y, Wang X, Garfield DH, Huang O, et al. PD-1(+) immune cell infiltration inversely correlates with survival of operable breast cancer patients. Cancer Immunol Immunother. 2014 Apr;63(4):395-406. 
35. Kroemer G, Galluzzi L, Zitvogel L, Fridman WH. Colorectal cancer: the first neoplasia found to be under immunosurveillance and the last one to respond to immunotherapy? Oncoimmunology. 2015 Jul;4(7):e1058597.

36. Lu C, Redd PS, Lee JR, Savage N, Liu K. The expression profiles and regulation of PD-L1 in tumorinduced myeloid-derived suppressor cells. Oncoimmunology. 2016;5(12):e1247135.

37. Sagiv-Barfi I, Kohrt HEK, Czerwinski DK, Ng PP, Chang BY, Levy R. Therapeutic antitumor immunity by checkpoint blockade is enhanced by ibrutinib, an inhibitor of both BTK and ITK. Proc Natl Acad Sci U S A. 2015 Mar;112(9):E966-72.

38. Combaz-Lair C, Galateau-Salle F, McLeer-Florin A, Le Stang N, David-Boudet L, Duruisseaux M, et al. Immune biomarkers PD-1/PD-L1 and TLR3 in malignant pleural mesotheliomas. Hum Pathol. 2016 Jun;52:9-18.

39. Li Z, Lai Y, Sun L, Zhang X, Liu R, Feng G, et al. PD-L1 expression is associated with massive lymphocyte infiltration and histology in gastric cancer. Hum Pathol. 2016 Sep;55:182-9.

40. Hecht M, Buttner-Herold M, Erlenbach-Wunsch K, Haderlein M, Croner R, Grutzmann R, et al. PD-L1 is upregulated by radiochemotherapy in rectal adenocarcinoma patients and associated with a favourable prognosis. Eur J Cancer. 2016 Sep;65:52-60.

41. Gentzler R, Hall R, Kunk PR, Gaughan E, Dillon P, Slingluff CLJ, et al. Beyond melanoma: inhibiting the PD-1/PD-L1 pathway in solid tumors. Immunotherapy. 2016 May;8(5):583-600.

42. Zhang Y, Kang S, Shen J, He J, Jiang L, Wang W, et al. Prognostic significance of programmed cell death 1 (PD-1) or PD-1 ligand 1 (PD-L1) Expression in epithelial-originated cancer: a meta-analysis. Medicine (Baltimore). 2015 Feb;94(6):e515.

43. Lu B, Chen L, Liu L, Zhu Y, Wu C, Jiang J, et al. T-cell-mediated tumor immune surveillance and expression of $\mathrm{B} 7 \mathrm{co}-\mathrm{inhibitory}$ molecules in cancers of the upper gastrointestinal tract. Immunol Res. 2011 Aug;50(2-3):269-75.

44. Jin Z, Yoon HH. The promise of PD-1 inhibitors in gastro-esophageal cancers: microsatellite instability vs. PD-L1. J Gastrointest Oncol. 2016 Oct;7(5):771-88.

45. Taieb J, Moehler M, Boku N, Ajani JA, Yanez Ruiz E, Ryu M-H, et al. Evolution of checkpoint inhibitors for the treatment of metastatic gastric cancers: Current status and future perspectives. Cancer Treat Rev. 2018 May;66:104-13.

46. Azoury Ukrainiand C S yi, Straughan DM, Shukla V. Immune Checkpoint Inhibitors for Cancer Therapy: Clinical Efficacy and Safety. Curr Cancer Drug Targets. 2015;15(6):452-62.

47. Shi F, Shi M, Zeng Z, Qi R-Z, Liu Z-W, Zhang J-Y, et al. PD-1 and PD-L1 upregulation promotes CD8(+) T-cell apoptosis and postoperative recurrence in hepatocellular carcinoma patients. Int $\mathrm{J}$ cancer. 2011 Feb;128(4):887-96.

48. Gao Q, Wang X-Y, Qiu S-J, Yamato I, Sho M, Nakajima Y, et al. Overexpression of PD-L1 significantly associates with tumor aggressiveness and postoperative recurrence in human hepatocellular carcinoma. Clin Cancer Res. 2009 Feb;15(3):971-9. 
49. Herbst RS, Baas P, Kim D-W, Felip E, Perez-Gracia JL, Han J-Y, et al. Pembrolizumab versus docetaxel for previously treated, PD-L1-positive, advanced non-small-cell lung cancer (KEYNOTE-010): a randomised controlled trial. Lancet (London, England). 2016 Apr;387(10027):1540-50.

50. Buchbinder El, Dutcher JP, Daniels GA, Curti BD, Patel SP, Holtan SG, et al. Therapy with high-dose Interleukin-2 (HD IL-2) in metastatic melanoma and renal cell carcinoma following PD1 or PDL1 inhibition. J Immunother cancer. 2019 Feb;7(1):49.

51. Kelly RJ. Immunotherapy for Esophageal and Gastric Cancer. Am Soc Clin Oncol Educ book Am Soc Clin Oncol Annu Meet. 2017;37:292-300.

52. Panarese I, De Vita F, Ronchi A, Romano M, Alfano R, Di Martino N, et al. Predictive biomarkers along gastric cancer pathogenetic pathways. Expert Rev Anticancer Ther. 2017 May;17(5):417-25.

53. Vetizou M, Daillere R, Zitvogel L. [Gut microbiota and efficacy of cancer therapies]. Biol Aujourdhui. 2017;211(1):51-67.

54. Gagniere J, Raisch J, Veziant J, Barnich N, Bonnet R, Buc E, et al. Gut microbiota imbalance and colorectal cancer. World J Gastroenterol. 2016 Jan;22(2):501-18.

55. Cariani E, Pilli M, Zerbini A, Rota C, Olivani A, Pelosi G, et al. Immunological and molecular correlates of disease recurrence after liver resection for hepatocellular carcinoma. PLoS One. 2012;7(3):e32493.

56. L E. Theory and practise of the g-index. Scientometrics. 2006;69:131-52.

57. Chen. The centrality of pivotal points in the evolution of scientific networks. In: 10th international conference on Intelligent user interfaces. 2005. p. 98-105.

58. Kleinberg J. Bursty and Hierarchical Structure in Streams. Data Min Knowl Discov. 2003;7(4):37397.

59. Stanisław Osiński DW. Carrot2: Design of a Flexible and Efficient Web Information Retrieval Framework. In: International Atlantic Web Intelligence Conference. 2005. p. 439-44.

60. Chen C, Paul RJ, Keefe BO. Fitting the Jigsaw of Citation: Information Visualization in Domain Analysis. 2001;52(4):315-30.

\section{Tables}

Table1. Top 5 manuscripts retrieved based on simplified co-citation network, betweenness centrality, and burstiness 


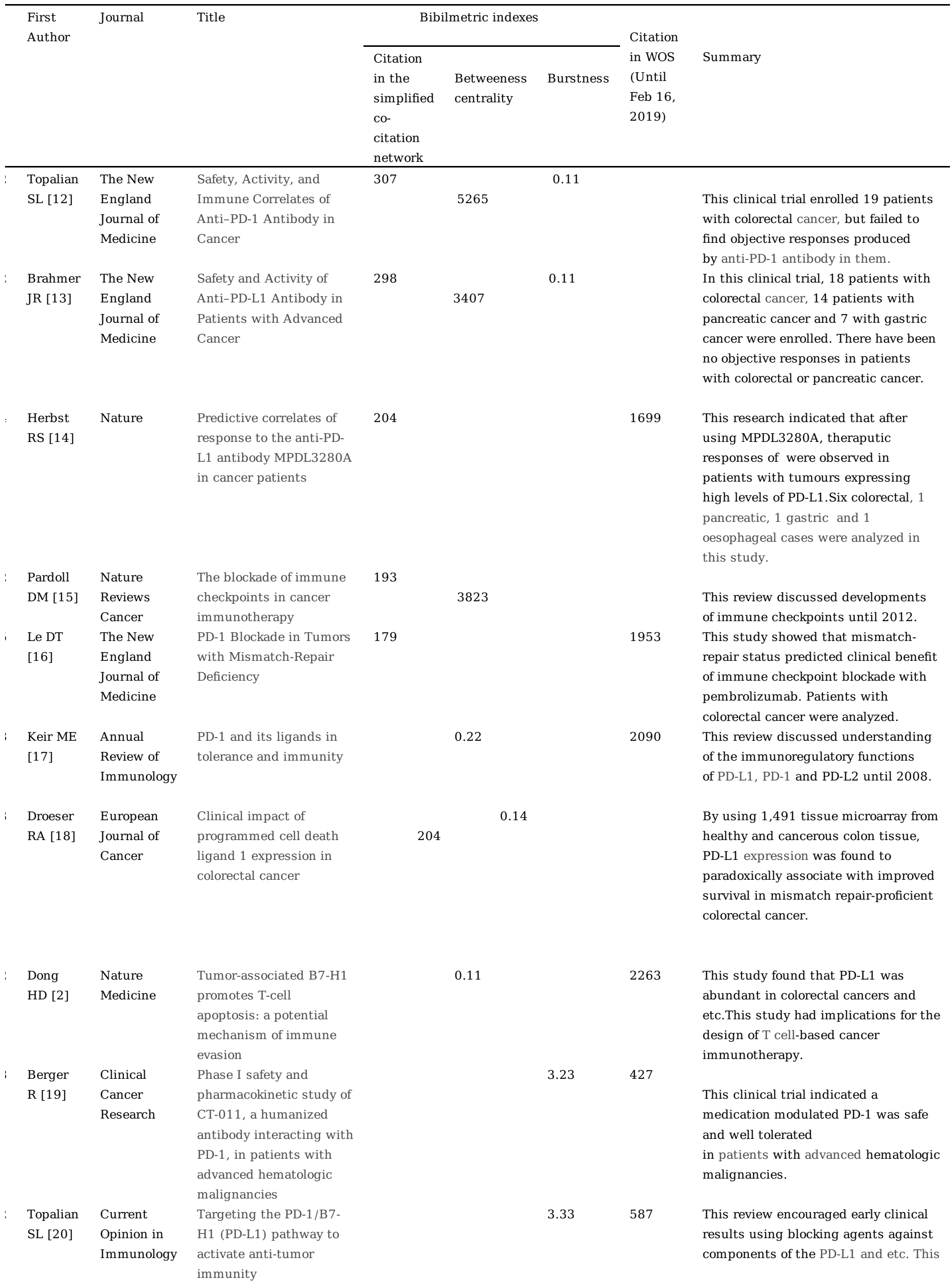


review mentioned the clinical trail in colorectal cancer.

\begin{tabular}{|c|c|c|c|c|c|}
\hline $\begin{array}{l}\text { Blank C } \\
\text { [21] }\end{array}$ & $\begin{array}{l}\text { Cancer } \\
\text { Research }\end{array}$ & $\begin{array}{l}\text { PD-L1/B7H-1 inhibits } \\
\text { the effector phase of } \\
\text { tumor rejection by T cell } \\
\text { receptor (TCR) } \\
\text { transgenic CD8+ T cells }\end{array}$ & 3.33 & 426 & $\begin{array}{l}\text { This study supported interfering } \\
\text { with PD-L1/PD-1 interactions to } \\
\text { augment the effector function } \\
\text { of tumor antigen- } \\
\text { specific CD8(+) T cells in } \\
\text { the tumor microenvironment. }\end{array}$ \\
\hline $\begin{array}{l}\text { Konishi } \\
\text { J [22] }\end{array}$ & $\begin{array}{l}\text { Clinical } \\
\text { Cancer } \\
\text { Research }\end{array}$ & $\begin{array}{l}\text { B7-H1 Expression on } \\
\text { Non-Small Cell Lung } \\
\text { Cancer Cells and Its } \\
\text { Relationship with Tumor- } \\
\text { Infiltrating Lymphocytes } \\
\text { and Their PD-1 } \\
\text { Expression }\end{array}$ & 3.34 & 450 & $\begin{array}{l}\text { This study suggestted that in non- } \\
\text { small cell lung cancers, } \\
\text { the expression of pd- } \\
11 \text { on tumor cells in local areas } \\
\text { reciprocally correlated with the } \\
\text { number of tumor-infiltrating } \\
\text { lymphocytes. }\end{array}$ \\
\hline
\end{tabular}

Table 2. Summaries of Top 5 studies in 2017 and 2018 according to total citation in a completed cocitation network 


\begin{tabular}{|c|c|c|c|c|c|}
\hline Year & First Author & Journal & Title & $\begin{array}{l}\text { Citation } \\
\text { in a co- } \\
\text { citation } \\
\text { network }\end{array}$ & Summary \\
\hline 2017 & Le DT [23] & Science & $\begin{array}{l}\text { Mismatch-repair deficiency predicts response of solid } \\
\text { tumors to PD-1 blockade. }\end{array}$ & 52 & $\begin{array}{l}\text { This study suggestted that the large } \\
\text { proportion of mutant neoantigens in } \\
\text { mismatch repair-deficient cancers make } \\
\text { them sensitive to immune PD-1blockade, } \\
\text { regardless of the cancers' tissue of origin. }\end{array}$ \\
\hline 2017 & $\begin{array}{l}\text { El-khoueiry AB } \\
\text { [8] }\end{array}$ & Lancet & $\begin{array}{l}\text { Nivolumab in patients with advanced hepatocellular } \\
\text { carcinoma (CheckMate 040): an open-label, non- } \\
\text { comparative, phase } 1 / 2 \text { dose escalation and expansion trial. }\end{array}$ & 40 & $\begin{array}{l}\text { This study suggestted in advanced } \\
\text { hepatocellular carcinoma, Nivolumab, a PD- } \\
1 \text { inhibitor, had a manageable safety profile } \\
\text { and durable objective responses. }\end{array}$ \\
\hline 2017 & $\begin{array}{l}\text { Thompson ED } \\
\text { [24] }\end{array}$ & Gut & $\begin{array}{l}\text { Patterns of PD-L1 expression and CD8 T cell infiltration in } \\
\text { gastric adenocarcinomas and associated immune stroma. }\end{array}$ & 33 & $\begin{array}{l}\text { This study suggestted that in gastric and } \\
\text { gastro-oesophageal junction cancers, } \\
\text { patients with higher CD8+ T cell densities } \\
\text { also had higher PD-L1 expression, and was } \\
\text { correlated with prognosis. }\end{array}$ \\
\hline 2017 & Kang YK [25] & Lancet & $\begin{array}{l}\text { Nivolumab in patients with advanced gastric or gastro- } \\
\text { oesophageal junction cancer refractory to, or intolerant of, } \\
\text { at least two previous chemotherapy regimens (ONO-4538- } \\
12 \text {, ATTRACTION-2): a randomised, double-blind, placebo- } \\
\text { controlled, phase } 3 \text { trial. }\end{array}$ & 27 & $\begin{array}{l}\text { This phase } 3 \text { clinical study suggestted that } \\
\text { in advanced gastric or gastro-oesophageal } \\
\text { junction cancer, Nivolumab, a PD-1 } \\
\text { inhibitor, might be a new treatment option. }\end{array}$ \\
\hline 2017 & Chen DS [26] & Nature & $\begin{array}{l}\text { Elements of cancer immunity and the cancer-immune set } \\
\text { point. }\end{array}$ & 26 & $\begin{array}{l}\text { This review summarized recent advanced } \\
\text { in immune check-points, including PD-L1, } \\
\text { PD-1, CTLA-4. This review did not directly } \\
\text { discuss pd-11 in gastrointenstinal cancers. }\end{array}$ \\
\hline 2018 & $\begin{array}{l}\text { Gopalakrishnan } \\
\text { V [27] }\end{array}$ & Science & $\begin{array}{l}\text { Gut microbiome modulates response to anti-PD-1 } \\
\text { immunotherapy in melanoma patients. }\end{array}$ & 13 & $\begin{array}{l}\text { This study suggessted in human } \\
\text { cancer patients, gut microbiome modulates } \\
\text { tumor response to checkpoint blockade } \\
\text { immunotherapy. This study was done in } \\
\text { melanoma patients. }\end{array}$ \\
\hline 2018 & Routy B [28] & Science & $\begin{array}{l}\text { Gut microbiome influences efficacy of PD-1-based } \\
\text { immunotherapy against epithelial tumors. }\end{array}$ & 12 & $\begin{array}{l}\text { This study revealed that primary resistance } \\
\text { to immune checkpoint inhibitors can be } \\
\text { attributed to abnormal gut microbiome } \\
\text { composition. }\end{array}$ \\
\hline 2018 & Matson V [29] & Science & $\begin{array}{l}\text { The commensal microbiome is associated with anti-PD-1 } \\
\text { efficacy in metastatic melanoma patients. }\end{array}$ & 11 & $\begin{array}{l}\text { This study suggestted that the microbiome } \\
\text { might have a mechanistic impact on } \\
\text { immune checkpoint therapy in human } \\
\text { cancer cases. }\end{array}$ \\
\hline 2018 & $\begin{array}{l}\text { Hellmann MD } \\
\text { [30] }\end{array}$ & $\begin{array}{l}\text { New } \\
\text { England } \\
\text { Journal } \\
\text { of } \\
\text { Medicine }\end{array}$ & $\begin{array}{l}\text { Nivolumab plus Ipilimumab in Lung Cancer with a High } \\
\text { Tumor Mutational Burden. }\end{array}$ & 8 & $\begin{array}{l}\text { This phase } 3 \text { clinical trial validated the } \\
\text { benefit of ipilimumab (a PD-L1 inhibitor) } \\
\text { plus nivolumab (a PD-1 inhibitor) in non } \\
\text { small cell lung cancer. }\end{array}$ \\
\hline 2018 & $\begin{array}{l}\text { Mariathasan S } \\
\text { [31] }\end{array}$ & Nature & $\begin{array}{l}\text { TGF } \beta \text { attenuates tumour response to PD-L1 blockade by } \\
\text { contributing to exclusion of T cells. }\end{array}$ & 8 & $\begin{array}{l}\text { This study revealed that primary resistance } \\
\text { to immune checkpoint inhibitors can be } \\
\text { attributed to abnormal gut microbiome } \\
\text { composition. }\end{array}$ \\
\hline
\end{tabular}

Table 3. Ten author keywords identified by the index of burstness since 2014 


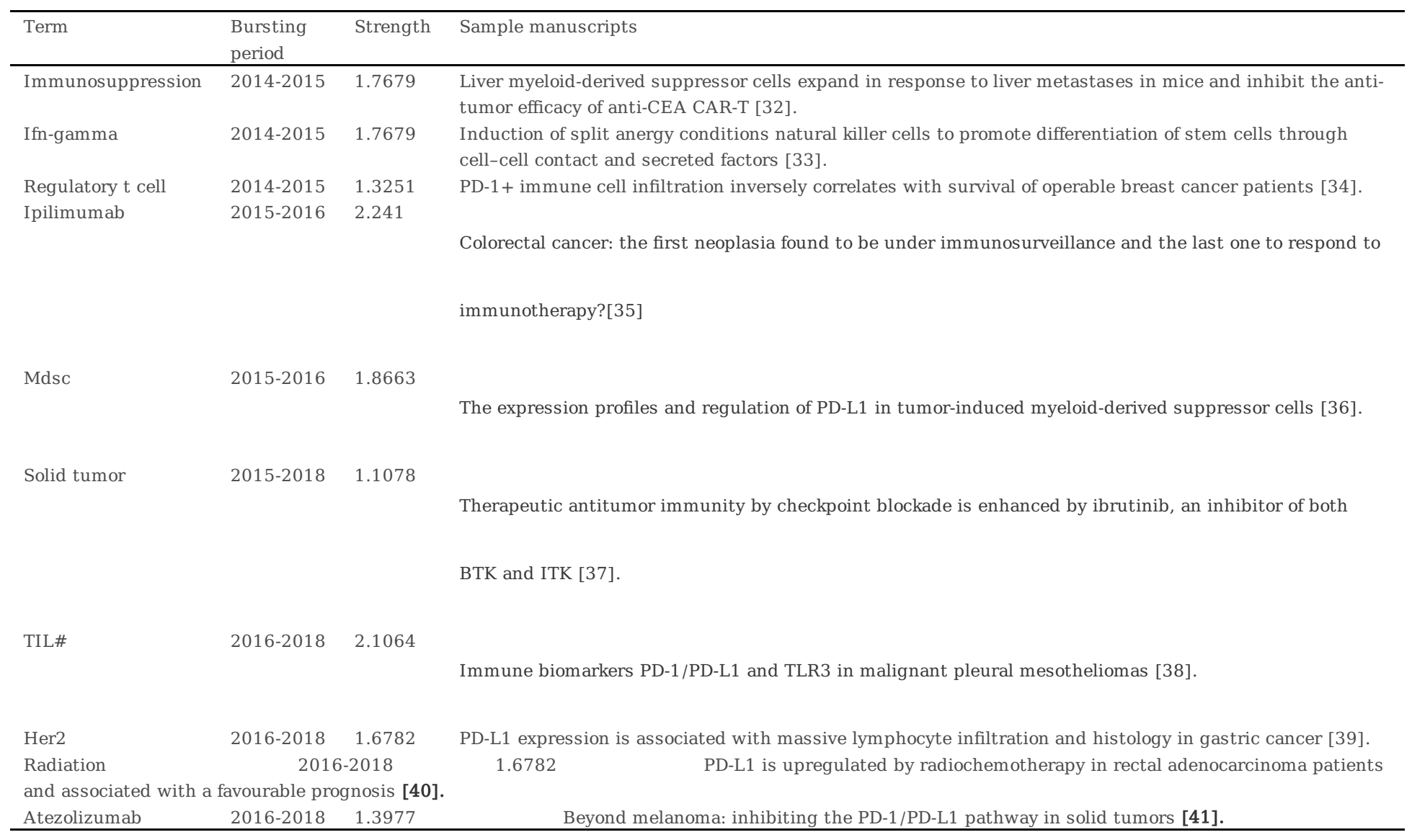

Table 4. Clustering in different types of gastrointenstinal cancers

\section{Figures}




\begin{tabular}{|c|c|c|c|c|c|}
\hline \multirow[t]{2}{*}{ Type of cancer } & \multicolumn{3}{|c|}{ Process for clustering } & \multirow{2}{*}{$\begin{array}{l}\text { Term to summarize } \\
\text { the largest three } \\
\text { clusters }\end{array}$} & \multirow[t]{2}{*}{ Sample paper in each cluster } \\
\hline & Modularity & $\begin{array}{l}\text { Mean } \\
\text { silhouette } \\
\text { value }\end{array}$ & $\begin{array}{l}\text { Number } \\
\text { of } \\
\text { clusters }\end{array}$ & & \\
\hline \multirow{4}{*}{$\begin{array}{l}\text { Colorectal } \\
\text { cancer }\end{array}$} & 0.6179 & 0.4239 & 32 & & \\
\hline & & & & Predictive biomarker & $\begin{array}{l}\text { Predictive biomarkers in pd-1/pd-11 checkpoint } \\
\text { blockade immunotherapy [4]. }\end{array}$ \\
\hline & & & & Advanced cancer & $\begin{array}{l}\text { Safety and activity of anti-pd-11 antibody in patients } \\
\text { with advanced cancer [13]. }\end{array}$ \\
\hline & & & & Prognostic significance & $\begin{array}{l}\text { Prognostic significance of programmed cell death } 1 \text { (pd- } \\
\text { 1) or pd-1 ligand } 1 \text { (pd-11) expression in } \\
\text { epithelial-originated cancer a meta-analysis [42]. }\end{array}$ \\
\hline \multirow{4}{*}{$\begin{array}{l}\text { Gastro- } \\
\text { esophageal } \\
\text { cancer }\end{array}$} & 0.22 & 0.7112 & 8 & & \\
\hline & & & & $\begin{array}{l}\text { upper gastrointestinal } \\
\text { tract }\end{array}$ & $\begin{array}{l}\text { T-cell-mediated tumor immune surveillance and } \\
\text { expression of b7 co-inhibitory molecules in cancers } \\
\text { of the upper gastrointestinal tract [43]. }\end{array}$ \\
\hline & & & & $\begin{array}{l}\text { microsatellite } \\
\text { instability }\end{array}$ & $\begin{array}{l}\text { The promise of pd-1 inhibitors in gastro-esophageal } \\
\text { cancers: microsatellite instability vs. pd-11 [44]. }\end{array}$ \\
\hline & & & & future perspective & $\begin{array}{l}\text { Evolution of checkpoint inhibitors for the treatment of } \\
\text { metastatic gastric cancers: } \\
\text { current status and future perspective [45]. }\end{array}$ \\
\hline \multirow{4}{*}{$\begin{array}{l}\text { Hepato- } \\
\text { panceato-biliary } \\
\text { cancer }\end{array}$} & 0.5812 & 0.4139 & 25 & & \\
\hline & & & & clinical efficacy & $\begin{array}{l}\text { Immune checkpoint inhibitors for cancer therapy: } \\
\text { clinical efficacy and safety [46]. }\end{array}$ \\
\hline & & & & Intergrative analysis & $\begin{array}{l}\text { PD-1 and PD-L1 upregulation promotes CD8+ T-cell } \\
\text { apoptosis and postoperative recurrence in } \\
\text { hepatocellular carcinoma patients [47]. }\end{array}$ \\
\hline & & & & $\begin{array}{l}\text { human hepatocellular } \\
\text { carcinoma }\end{array}$ & $\begin{array}{l}\text { Overexpression of pd-11 significantly associates with } \\
\text { tumor aggressiveness and postoperative recurrence } \\
\text { in human hepatocellular carcinoma [48]. }\end{array}$ \\
\hline
\end{tabular}




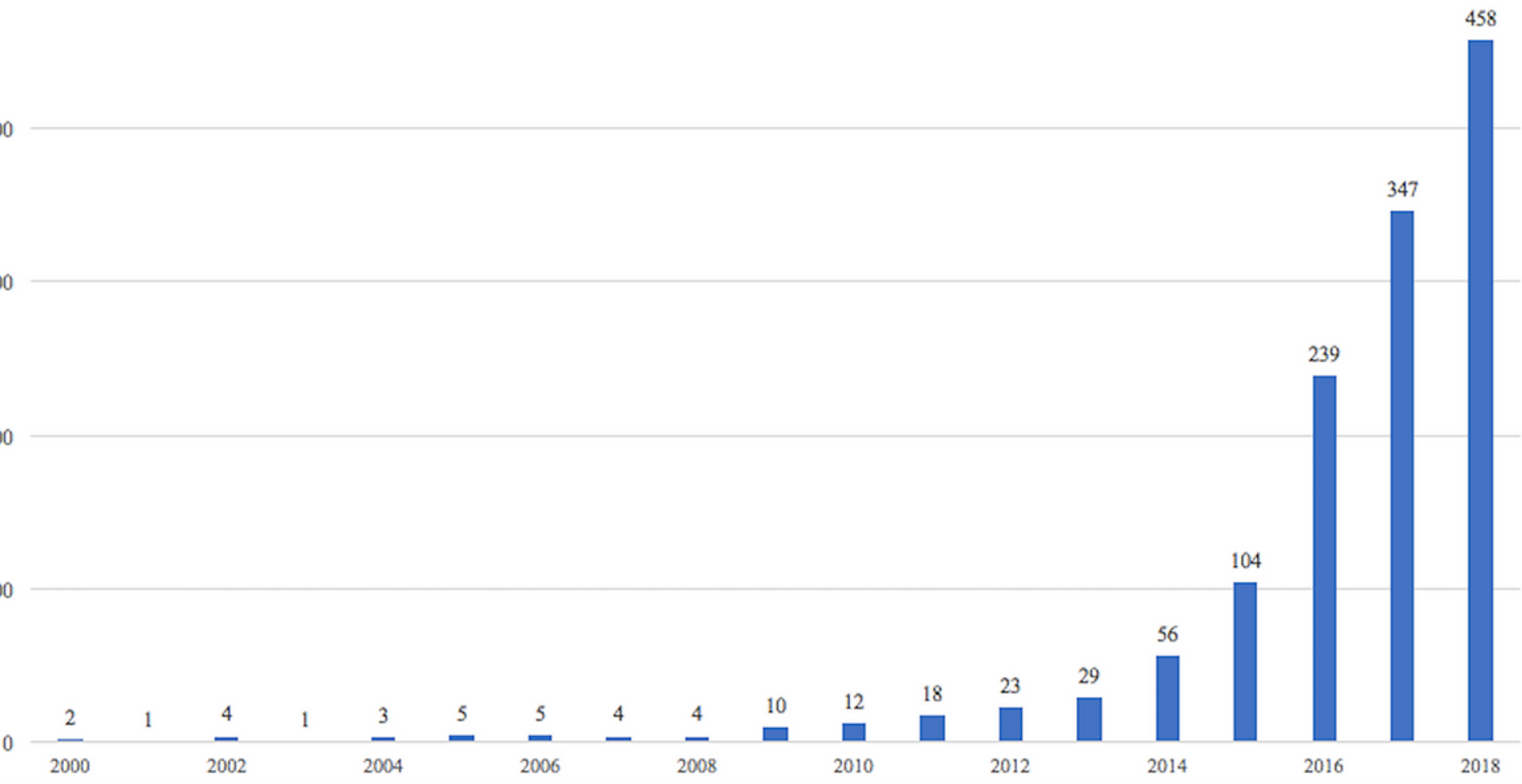

\section{Figure 2}

Annual publications about pd-11 in gastrointestinal cancers

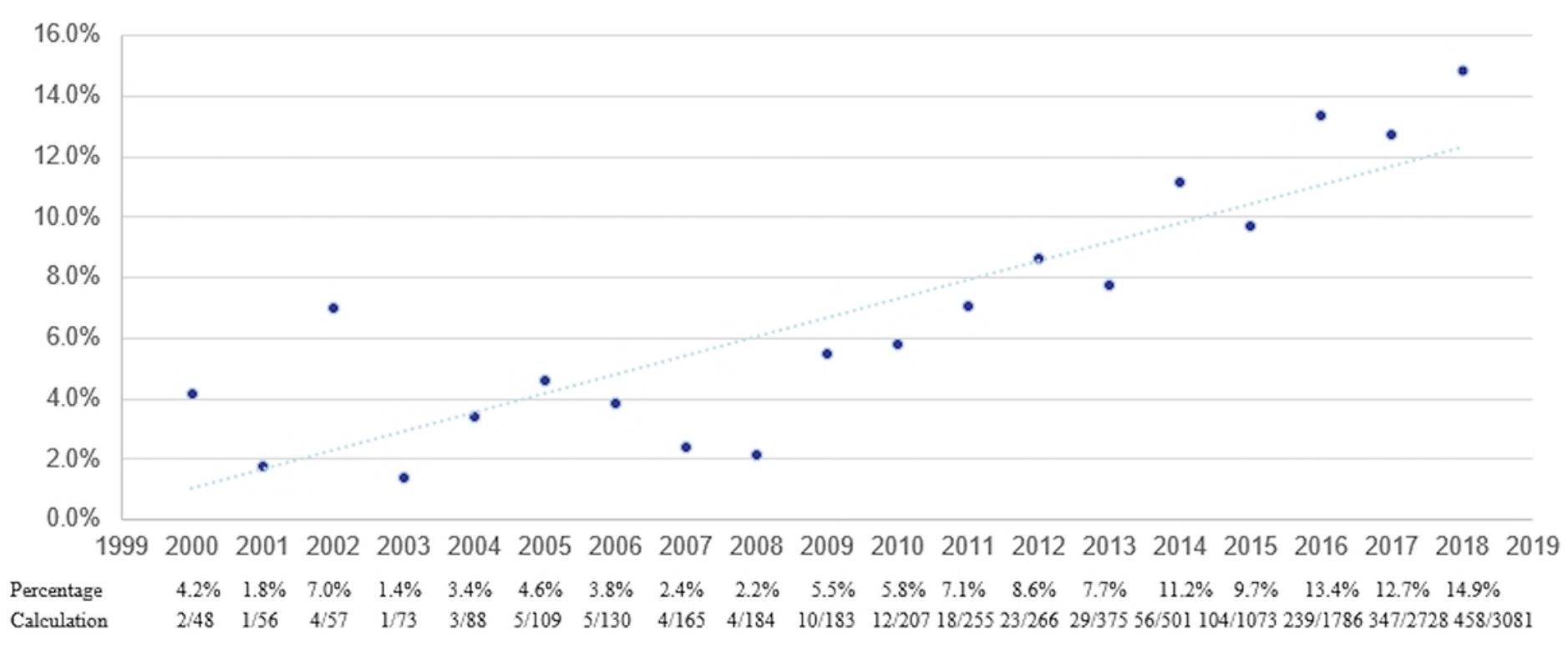

\section{Figure 4}

The percentage of publication on gastrointestinal cancers in the whole science domain of PD-L1 


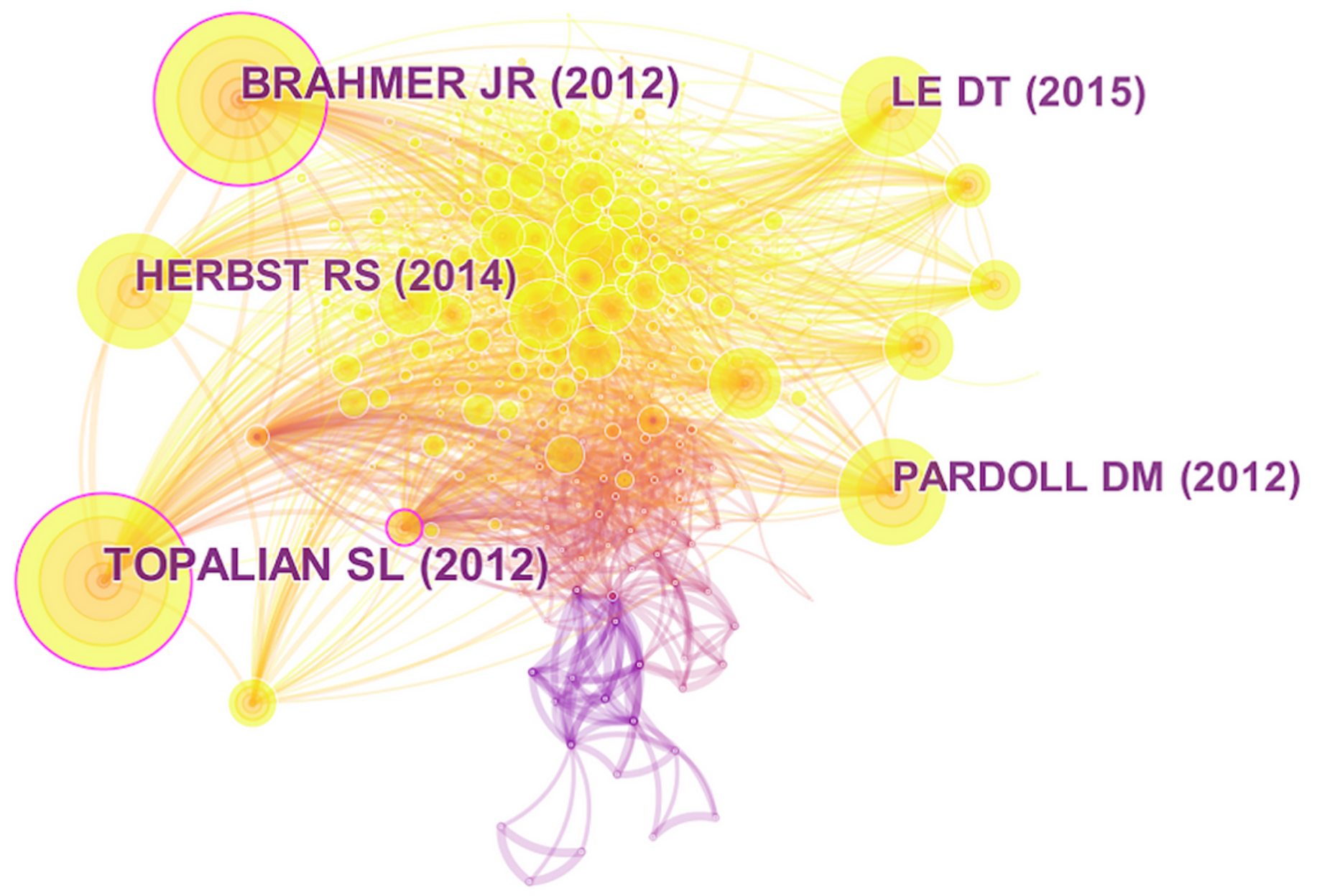

Figure 6

A simplified co-citation network of references about pd-I1 in gastrointestinal cancers A

Figure 8

Key concepts about pd-11 in gastrointestinal cancers (circled in red line) 


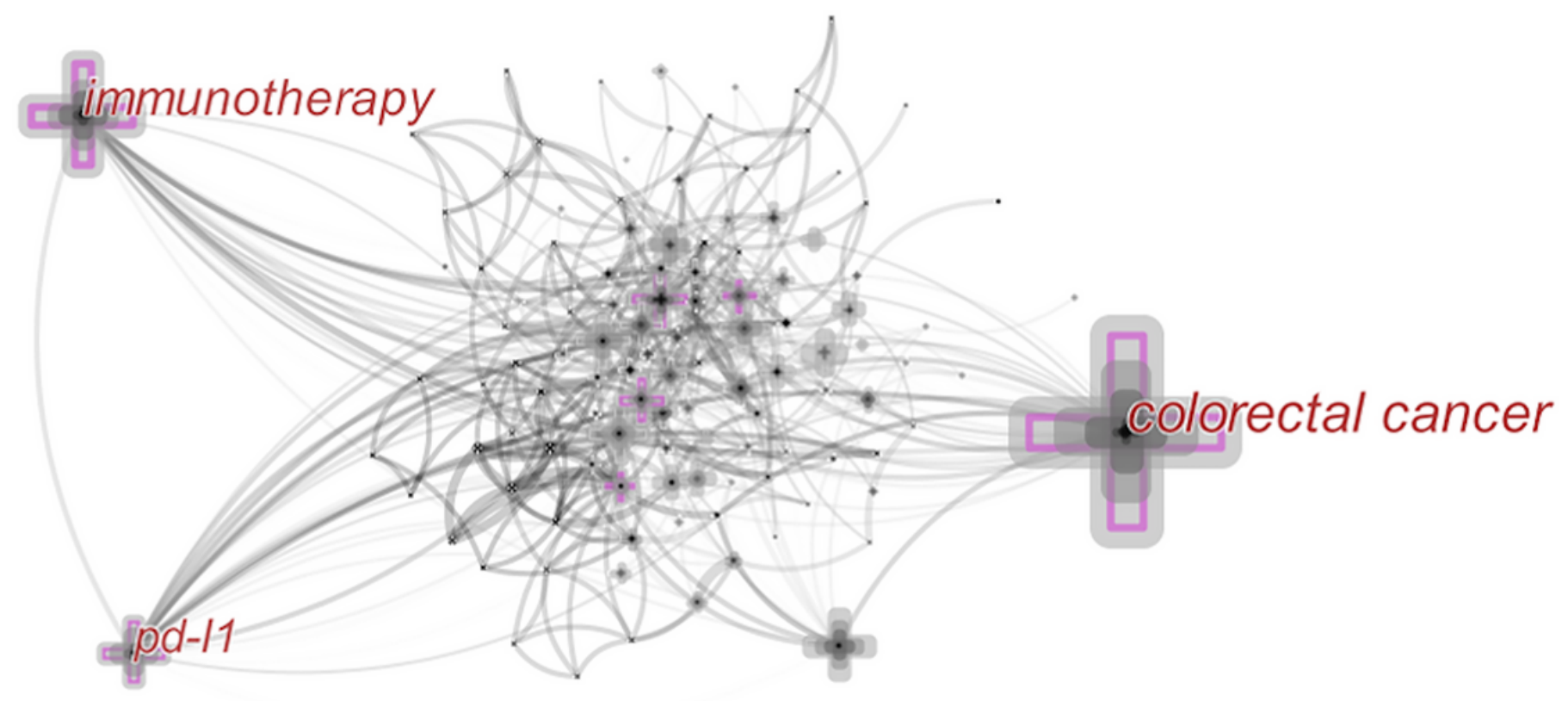

Figure 10

A simplified co-citation network of author keywords since 2014
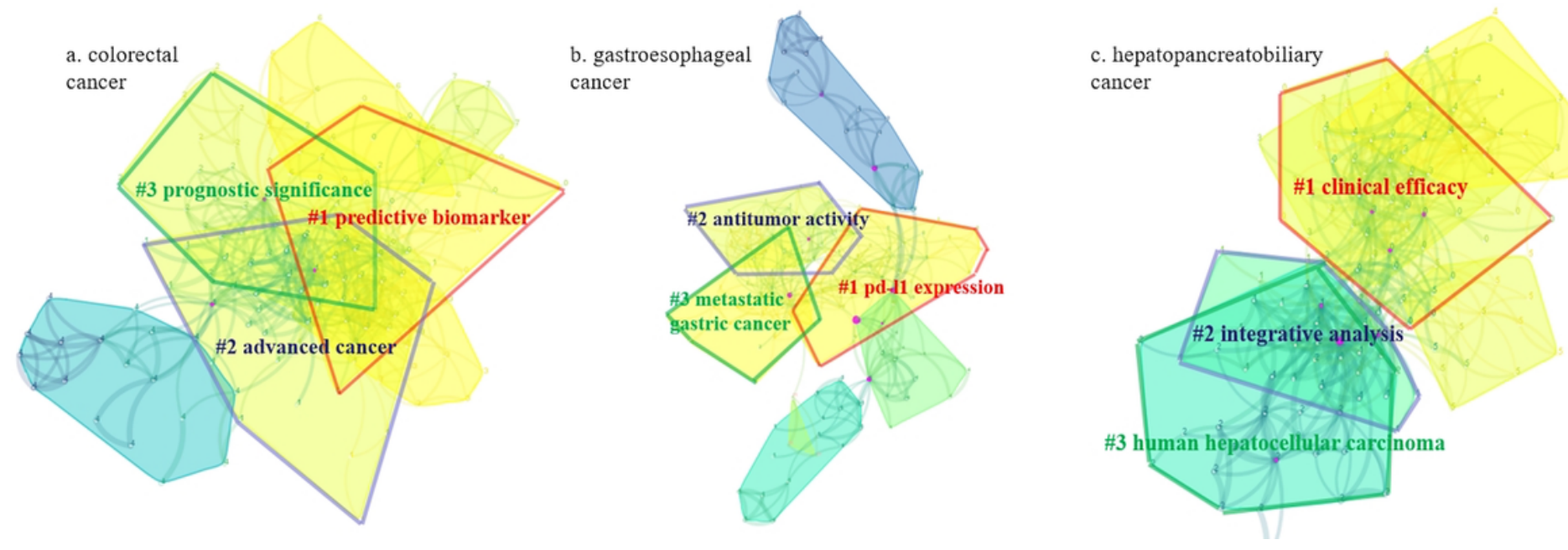

Figure 12

Clustering in colorectal, gastroesophageal, and hepatopancreatobiliary cancers 